\title{
A Socio-Emancipatory Perspective on the Teaching of English as a Foreign Language to the Deaf
}

\author{
Antonio Henrique Coutelo de Moraes ${ }^{1,2^{*}}$ Solange Maria de Barros ${ }^{1}$ \\ 1.Postgraduate Program in Language Studies, Federal University of Mato Grosso, 2367 Fernando Correa da \\ Costa Street, Cuiabá 78060-900, Brazil \\ 2.Postgraduate Program in Language Sciences, Catholic University of Pernambuco, 526 Príncipe Street, Recife \\ 50050-900, Brazil \\ * E-mail of the corresponding author: antonio.moraes@unicap.br
}

\begin{abstract}
The objective of this research was to draw, in the light of Critical Realism (CR) and Critical Discourse Analysis (CDA), some interdisciplinary reflections that could contribute to an emancipatory perspective in the teaching of English language for the deaf. The challenge, it seems to us, is to look for mechanisms and causal powers in an attempt to overcome obstacles in the classroom, at school. Teachers' fight in defence of quality teaching of the English language to the deaf and of pedagogical activities that contribute to the (self)emancipation of these students revealed that these teachers are active causal agents in the emancipation process. We expect to contribute to English-language teaching and learning to the deaf, bringing a socio-emancipatory outlook on this process.
\end{abstract}

Keywords: English language, teaching, critical discourse analysis, critical realism

DOI: $10.7176 /$ RHSS/10-17-01

Publication date:October $31^{\text {st }} 2020$

\section{Introduction}

The teaching of foreign languages to the deaf, more specifically the English language, is a paradoxical theme and consists of many obstacles, mainly because it refers to linguistic work in a hegemonic language with a socially marginalized group in Brazil.

This article is based on qualitative, bibliographic research in progress about didactic proposals for teaching English as a foreign language to deaf students in bilingual and/or inclusive educational contexts, in order to contribute to the empowerment and emancipation of the deaf, which, for Bhaskar (1998), cannot be achieved only through the change of consciousness, being necessary that it also occurs in practice.

We consider it relevant to highlight, beforehand, that we know that deafness is a sensory loss that can compromise the acquisition and learning of any oral-auditory language in a natural way, which does not occur with sign language. (Moraes 2012, 2018). However, we always believe it is necessary to recognize that the difficulty with communication generated by deafness can be minimized by the adoption of social bilingualism as the main resource.

According to Grosjean (1999), knowing and using sign language and one or more oral languages, the deaf will achieve a complete development of their cognitive, linguistic, and social skills. Sign language will facilitate the acquisition of oral languages, either in written or spoken form. It is known that a first language acquired with normality, whether it is an oral language or a sign language, will greatly stimulate the acquisition of a second language (Grosjean 1999). Finally, we add that this context will also stimulate the acquisition of a foreign language.

This research takes place in a bilingual perspective because we consider that deaf people, in general, have a good command of sign language (L1) and knowledge of Portuguese (L2) when they are initiated in a foreign language (LE).

Therefore, the objective of this research was to draw some theoretical reflections on critical English language education for the deaf. To this end, we sought support in elements of Fairclough's (2010) Critical Discourse Analysis and Bhaskar's (1998) Critical Realism.

\section{Contributions of Bhaskar's Critical Realism}

As indicated in the introduction, this article starts with ongoing research on didactic proposals for teaching English as a foreign language to the deaf and aims to contribute to the empowerment and emancipation of the deaf student. For Bhaskar (1998), emancipation cannot be achieved only through the change of consciousness, it is necessary that it occurs in practice. In this sense, as transformers, teachers need to make didactic choices, for example, that allow the deaf to learn the English language in order to expand their access to information. The more languages an individual knows, the greater the range of information they have access to, especially when it comes to the English language, which is hegemonic and mediates various activities in the human sphere in a globalized world. In this sense, analysing didactic proposals for teaching the English language to the deaf represents a challenge because it is a hegemonic language, of power, and of a group still marginalized in society.

In this perspective, Roy Bhaskar's Critical Realism (CR) represents an alternative for our research, 
considering that the world does not consist only of events or facts (Barros 2015). In other words, 'the real is denser, that is, it consists of an objective world that distinguishes a surface from something even deeper' (Barros 2015: 22).

For Bhaskar (1998), CR, as an emancipatory philosophy, can serve as a basis for research that seeks to understand the interrelationships between individuals and society, as well as promoting social transformation, based on the understanding of structures/networks of real relationships 'that operate and act in the world regardless of our knowledge, our experience' (p. 19).

Thus, as Barros (2015 p. 27) puts it, 'science must serve to reveal something that serves to transform social reality', although this reality consists of unobservable dimensions.

In this regard, Barros (2015) comments that knowledge needs to make sense so that reality can be transformed. It is necessary to penetrate the roots of social problems, with their structures, mechanisms, and powers, thus visualizing an explanatory criticism that can generate critical arguments in favour of social transformation.

In other words, one must seek to know and emphasize the logical connection between ways of explaining the social from a critical point of view in relation to the phenomenon that is being explained - which implies taking the researcher's position, in addition to adopting an interpretive view.

According to Barros (2009), CR refers to the idea that there is an external reality, regardless of the conceptions that one has of it.

Bhaskar (1998) proposes a distinction between the world and our experience, as well as its ontological stratification, that is, the question of Being, represented by the three domains of reality: The Real, the Realizable and the Empirical.

The domain of the Real can be understood as everything that exists in nature, be they natural (atomic structures and chemical structures), or social (ideas, social relations, modes of production, etc.) objects.

In turn, the Realizable domain consists of events or activities that are carried out and, therefore, generate effects of power, which may be observable or not.

Finally, the domain of the Empirical is understood as the domain of experience. If we take the example of a teacher, his physical and mental capacity is concentrated in the domain of the Real, while his work as an activity that generates a power effect is concentrated in the domain of the Realizable.

In this sense, human beings can only be studied scientifically as social beings. In his emancipatory and social transformation vision, according to Barros (2009), Bhaskar (1998) offers a promise for social science, since the mechanisms that generate problems can be removed. For the author, emancipation cannot be achieved just by changing consciousness; on the contrary, it must occur in practice.

Other relevant concepts are those of "causality", "causal powers" and "causal agents", which, according to Barros (2009), are used with some frequency by Critical Realism.

Therefore, as the researcher (Barros 2009) defends, to understand these concepts it is necessary, first, to clarify the term "causality". These are not just repeated experiences, but a category of experience.

Causality has knowledge value only for the phenomenon, it serves to describe and unify the experience, but it does not make the thing itself known (Barros 2015). Therefore, it is a question of the reality of the causal influence on which all human action is based, whether in everyday life or in education. Thus, the "cause" of a given phenomenon exists a priori from the knowledge one has about it (Bhaskar 1998).

CR understands that social life is not a closed system, on the contrary, it is an open system, in which any event is governed by emerging mechanisms or powers that operate simultaneously. In an open system, for example, it is not possible to identify certain sequences of events, otherwise the experimental activity would not make sense (Bhaskar 1998).

As Barros (2009) rightly points out, the crucial point of Bhaskar's argument is that the causal mechanisms that operate in experiments (natural science), continue to operate in the real world (as an open system), considering the independence of the causal mechanisms that are generated in a particular event.

Taking these concepts to the classroom context, the teacher can be considered a causal agent of a sequence of events because it allows to identify a possible causal relationship between two or more events.

In this sense, according to Bhaskar (1998) and Barros (2009), seeking to know the causes of the phenomena is unveiling the reality and the structures, mechanisms and trends that generate the events.

\section{Contributions of Fairclough's Critical Discourse Analysis}

Critical Discourse Analysis (CDA) understand CR as an explanation of social life (Chouliaraki \& Fairclough 1999 , Fairclough 2010, Barros 2009).

According to Barros (2009), Chouliaraki \& Fairclough (1999), in line with Bhaskar (1998), understand that there are several dimensions of social life, including physical, chemical, biological, economic, social, psychological and linguistic, and that these have distinct structures, with generative effects in the events, through particular mechanisms.

Inspired by Critical Realism, Chouliaraki \& Fairclough (1999) managed to organize an analytical model that 
made it possible to identify social problems materialized in oral or written texts. This opening up of transdisciplinary possibilities has made CDA increasingly gain space in critical social science, allowing discourse analysts an increasingly broader understanding of social life, especially in relation to micro and macrosocial elements (Barros 2009).

Also in line with Bhaskar (1998), Chouliaraki \& Fairclough (1999) affirm that CDA research must deal with practical problems of social life, envisioning an explanatory criticism built on the discoveries of social problems arising from social practices, and, as reinforces Barros (2015), based on them seek solutions to overcome these problems.

According to Bhaskar (1998), to reach the explanatory potential, the starting point is the analysis of how meanings are constructed in social practice. It is in this sense that Fairclough $(1989,2003)$ proposes a discourse analysis approach that can contribute to the growth of critical social research, since the CDA emphasizes the dialectical relationship between discourse and other elements of social practices.

Furthermore, Fairclough $(2010,2012)$ contributes with concepts of discourse and hegemony. Discourse concerns a type of social practice, representation and meaning of the world, that is, it is understood as a constituent of the social, as a mode of action, as it is one of the ways in which people can act on the world and about others, but it is also seen as a form of representation, because in it values and identities are represented in a particular way. In turn, hegemony according to Fairclough (2001 p. 122):

a) It is both leadership and the exercise of power in various areas of a society (economic, political, cultural, and ideological).

b) It is also the manifestation of the power of one of the classes economically defined as fundamental in alliance with other social forces over society as a whole, but never reaching, if only partially and temporarily, an 'unstable balance'.

c) It is also the construction of alliances and integration through concessions (more than the domination of subordinate classes).

d) It is, finally, a focus of constant fight over aspects of greater volatility between classes (and blocks), in order to build, maintain or even in order to break alliances and relations of domination and subordination that assume economic, political configurations and ideological.

The political concept of hegemony can be useful when applied to the analysis of discourse orders, since a given social structure of semiotic diversity can be hegemonic, become part of the legitimating common sense that sustains the relations of domination (Fairclough 2012). But the theorist points out, hegemony, in its periods of crisis, will always be contested to a greater or lesser extent. A discourse order is not a closed or rigid system, it is, in fact, an open system endangered by what happens in real interactions (Fairclough 2012).

\section{Emancipation and English language teaching to the deaf}

In this work, we present part of the study that is being carried out on didactic proposals for teaching the English language to the deaf. We seek to interpret the meanings constructed by the causal agents and their powers, that is, who these causal agents are and what causal powers they have.

In this regard, Barros (2009) states that the attempt to unveil these causal influences allows a better understanding of the micro and macrosocial contexts of the investigated phenomena.

Emancipation relies 'upon the transformation of structures, not the alteration or amelioration of states of affairs' (1998 p. 410). In this perspective, according to Burnett (2007), CR is grounded in scientific theory and also revolutionary in objective or intent.

Burnett (2007 para. 53) believes that 'it must also be recognised that enlightening people or facilitating selfenlightenment as to unwanted determinations or illusions is not a sufficient a condition in isolation and may lead to increased dissonance and despair'.

In this regard, Sayer (2000 p .160) states that 'for emancipation to take place the mechanisms generating the problems must be removed or blocked, which agrees with Bhaskar's (1998) theory.

Regarding inclusive education, we agree with Burnett's (2007) view that differences and diversity should be promoted and that we must seek to fully understand these in order to identify adaptations and changes needed to enable students with disabilities to enjoy what the researcher called 'improved wellbeing and equality of access to educational opportunities'.

In fact, we believe that there is not only the need to provide our students with access to education, but also to offer them favourable conditions for staying in school spaces.

As Burnett (2007) puts it, from a critical realistic perspective, it is only through the interrelation between individual and society that the transformation will be accomplished. The researcher therefore proposes that a departure from the duality of views currently present in many of the fields of disability towards the acceptance of causal relationships between society and the individual is useful in providing a path forward, particularly in the fields of inclusion and inclusive education.

Also, in line with a critical realist perspective, it is important to acknowledge that politics and policy influence 
the context people are working in (Burnett 2007). In the case of Brazil, linguistic policies point to bilingualism as the most appropriate option for the education of the deaf and suggest two classroom models: a bilingual one - in which there is the presence of a bilingual teacher who masters the oral-auditory language of the country and sign language, and an inclusive one, in which deaf students share space with their hearing peers and in which sign language teachers and interpreters mediate learning.

Studies on foreign language acquisition seem to show that, in the teaching-learning process of bilingual deaf people, theories of second language acquisition (L2) support the construction of, and work with, a third language (L3 which, in the in the case of this research, it is a foreign language - FL), which is mediated by sign language (L1) and Portuguese (L2).

In this regard, Cavalcanti \& Moraes (2011) affirm that the deaf person should have the opportunity to know their own language and Portuguese better during their school time or they may have more difficulty at the moment when it is necessary to learn a foreign language, in this case English, driven by different requirements.

During previous research, in direct interaction with deaf students, we observed that sign language worked well, and brought benefits as the language of instruction in the intervention with deaf subjects. Through it, for example, we gave instructions to deaf participants and discussed texts in English - their meanings and structures.

At the time, we observed that the use of this language allowed the deaf (subjects of the research) to exchange ideas and negotiate information with American deaf and deaf from other countries, as well as to exchange knowledge, learn the American sign language (ASL) and improve English, leading to a better understanding of the texts worked in class. This data shows us the possibility of emancipation of the deaf student from a positive investment on the part of educational agents and the deaf themselves, in addition to the change in conscience and in practice.

The experience gave these people the conditions to produce good texts, demystifying a belief that it would be almost impossible for the deaf to learn English since they also have difficulties to learn the Portuguese language. We also observed that sign language in foreign language instruction works as a motivating element for learning, since classes entirely in sign language are not common in regular education. However, researchers who observe school reality often find different data.

For this data analysis, we will work with scientific narratives by two researchers in the field of English language teaching for the deaf. We tried to stick with the understanding of the meanings constructed by Moraes (2018) and Sousa (2014), through the identification of causal agents and their powers.

According to Moraes (2018) and Sousa (2014), most English language teachers do not master the language of the deaf, which can slow down the process of teaching and learning the foreign language.

What is more common is that the English teacher, in inclusive classrooms, counts on the participation of the sign language interpreter, who, according to Moraes (2018), often does not know English, as well as not actively participating in classes, taking the deaf students to equal behaviour.

We also know that, in order for the sign language to be brought to the FL classroom as a mediator in teaching for the deaf, it is necessary that the interpreter, or the bilingual teacher, has not only a good level of knowledge in the three languages (sign language, Portuguese and English, in our case), but also an experience that allows this professional to know the cultural aspects inherent to them, which does not always happen.

Furthermore, according to Moraes (2018), English language teaching is still far from ideal for everyone, not just for deaf students. In previous research, we realized that little of the language is taught, with a focus on teaching about the language, that is, on the norms and the lexicon - which takes place, mostly, within a perspective that approaches the behaviourist-structuralist principles.

In the discourse of Moraes (2018) and Sousa (2014), it is possible to perceive challenges for the teaching of English language for the deaf, as illustrated in figure 1.

Figure 1. Causal determinants

\begin{tabular}{|c|c|c|}
\hline \multicolumn{3}{|c|}{ CAUSAL AGENTS AND THEIR POWERS } \\
\hline English teachers & The sign language & English language \\
do not master the & interpreter is often & teaching is still far \\
language of the & unfamiliar with & from ideal for all \\
deaf & English & \\
\hline
\end{tabular}

When saying "do not master", the researchers refer to the moment of their research (2014 and 2018), when it was already understood the importance of the English language teacher to know the sign language in order to interact directly with his deaf students, being able to solve doubts, besides motivating these students by showing 
interest in their particularities. To this lack of mastery, the researchers attribute the responsibility for the delay in learning the English language by deaf people.

As Moraes (2018 p. 155) points out, for example, the knowledge of sign language by the teacher, who knows the contents, would favour 'the establishment of a direct contact with all students, without missing important doubts' which are often they lose in moments of interpretation.

When saying that 'the interpreter often doesn't know English', the researchers refer to a harsh reality faced by students and interpreters. Will these professionals be held responsible for the lack of knowledge of the foreign language? Or would the responsibility be with the training institution where the interpreter has been? Or would it be with the school, which did not promote continuing education for the interpreter to learn the English language?

In saying 'English language teaching is still far from ideal for all', Moraes (2018 p. 146) uses a high degree of modalisation 'far below', revealing the low quality of English language teaching in the schools surveyed. By also stating 'being the focus on teaching about the language', his discourse reveals that language is not taught, language is not put into practice, and that teaching is limited to structures and their rules. But, again, whose responsibility would it be?

As can be seen, the task of recognizing the causal agents in these cases is difficult.

In the example illustrated below, Moraes (2018 p. 139) writes about an interviewed teacher, whom he called PB2 (Professor Bilingual). Let us see what he says:

'When asked about his knowledge of Libras [Brazilian Sign Language], PB2 replies: I studied it at CAS [Support Centre for the Deaf].'

'Her responses gave us hope that she would take the deaf student into account during her planning and teaching practice - which has been achieved satisfactorily in face of the possibilities.'

Moraes, when talking about the knowledge of sign language, mentions the course taken by the bilingual teacher, a causal agent with the power to make decisions that positively impact the teaching/learning of the English language to deaf people, for example when starting a sign language course to interact with her deaf students directly, without intermediaries.

In this other example illustrated below, Sousa (2014 p. 1032) tells about her own experience as an English teacher for deaf students:

'With no previous references to teaching English to the deaf in that school or my practice as a teacher, I had to find a way of my own and completely intuitive to teach English to the deaf.'

'Gradually, I was reflecting on my practice at that school and trying to improve it, as I was not satisfied with the students' performance. Despite my dissatisfaction, the students liked the classes very much, both because they were taught by a fluent teacher in Libras [Brazilian Sign Language] - a relatively recent fact at school - and because studying English was a stimulating novelty for them.'

Sousa, when reporting her experience with teaching English to the deaf, reveals an initial training - higher education - that disregards the diversity that the teacher may encounter in the practice of the profession. In addition, the researcher makes use of a strong modulation 'I had to' in her narrative, allowing us to reveal that Higher Education trains teachers for the average, for the average student. It is also evident that the researcher/teacher is a causal agent who has the power to change the reality of her classroom, breaking with negative paradigms so commonly disclosed.

Sousa also reveals that the critical-reflective work of the teacher and the search for specialization as a form of continuing education can empower professionals to transform themselves, transform their classroom and offer possibilities for their students to transform themselves.

Figure 2 with an exemplified scheme shows the agents and their causal powers. 
Figure 2. Causal agents and their powers

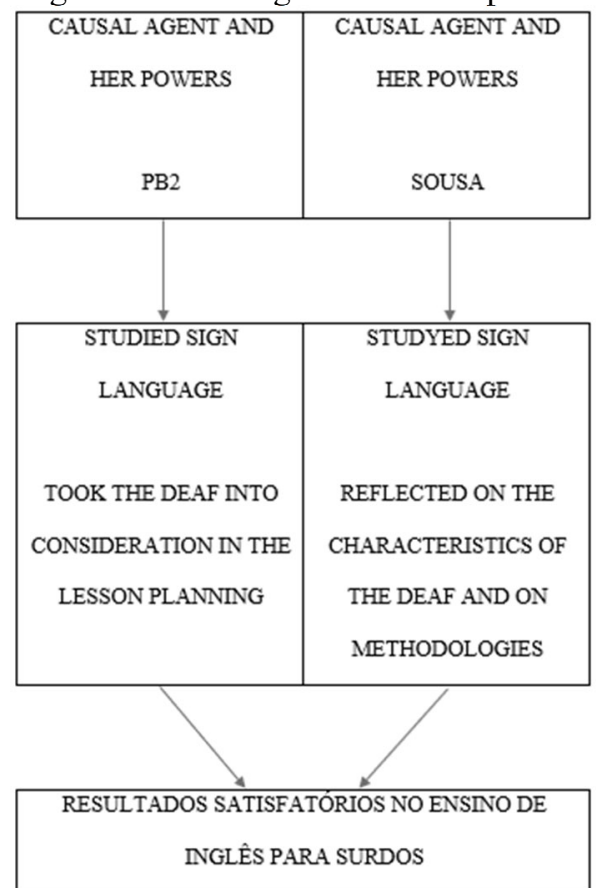

It can be seen here that the causal agents and their powers (PB2 and Sousa) were responsible for the successful teaching and learning of English to deaf people. As teachers, PB2 and Sousa deliberate on their training/education and theoretical-methodological choices for teaching practice. They are, in their institutions and realities, responsible for maintaining the conditions of permanence and learning of the deaf in their English language classes.

PB2 and Sousa, as causal agents responsible for the education of deaf students, have a power that is peculiar to them. As educators and committed to schools and their students, they showed a courageous attitude to dive into the universe of the unknown, learn sign language and critically reflect on their pedagogical practices, promoting quality learning and undoing crystallized beliefs that the deaf cannot learn a foreign language.

\section{Conclusion}

This article aimed to outline, in the light of CR and CDA, some interdisciplinary reflections that could contribute to an emancipatory perspective in the teaching of English to the deaf. We sought to understand the causal relationship between agents and their causal powers, for a better understanding of micro and macro-social contexts. We considered scientific narratives as a collection tool used to obtain data. Scientific narratives are useful by CDA in understanding the social mechanisms of domination and resistance or emancipation and social transformation insofar as they record not only quantitative data, but also discourse and impressions.

The use of this tool allowed to capture meanings in the discourses of PB2 and Sousa, through the narratives of the researchers Moraes (2018) and Sousa (2014). Their fight in defence of quality teaching of the English language to the deaf and of pedagogical activities that contribute to the (self)emancipation of these students revealed that these teachers are active causal agents in the emancipation process. By privileging the development of empowering social practices, PB2 and Sousa are also contributing to making their own pedagogical practice, in fact, transformative.

\section{References}

Barros, S. M. (2009). Realismo crítico e análise de discurso crítica: reflexões interdisciplinares para a formação do educador de línguas em processo de emancipação e transformação social. Polifonia, (17), 141-154.

Barros, S. M. (2015). Realismo Crítico e Emancipação Humana: contribuições ontológicas e epistemológicas para os estudos críticos do discurso. Pontes Editores.

Bhaskar, R. (1998). General Introduction. In M. Archer et alii (eds.). Critical Realism: Essential Readings. Routledge. (pp. ix-xxiv).

Burnett, N. B. (2007). Critical Realism: The required philosophical compass for inclusion?. Proceedings Australian Association of Research in Education: Research Impacts: Proving or improving? Fremantle. Western Australia.

Cavalcanti, W. M., \& Moraes, A. H. C. (2011). Aprendendo inglês: revisando alguns mitos sobre o ensino para surdos. In Faria, M, E. B., \& Cavalcante, M. (Eds.). Desafios para uma nova escola: um olhar sobre o processo ensino-aprendizagem de surdos. Editora da UFPB. (pp. 151-175). 
Chouliaraki, L., \& Fairclough, N. (1999). Discourse in late modernity. Rethinking critical discourse analysis. Edinburgh University Press.

Fairclough, N. (2001). Discurso e mudança social. Editora da Universidade de Brasília.

Fairclough, N. (2010). Critical Discourse Analysis. The Critical Study of Language. Longman.

Fairclough, N. Análise Crítica do Discurso como método em pesquisa social científica. Linha D'Água, 25(2), 307329.

Grosjean, F. (1999). O direito da criança surda de crescer bilíngue. Neuchâtel University Press.

Moraes, A. H. C. (2012). Descrição do desenvolvimento linguístico em língua inglesa por seis surdos: novos olhares sobre o processo de aquisição de uma língua. [Master's thesis, Catholic University of Pernambuco]. Unicap repository.

Moraes, A. H. C. (2018). A triangulação Libras-português-inglês: relatos de professores e intérpretes de Libras sobre aulas inclusivas de língua estrangeira. [Doctoral dissertation, Catholic University of Pernambuco]. Unicap repository.

Sayer, A. (2000). Realism and social science. Sage Publications.

Sousa, A. N. (2014). Reflexões sobre as práticas de ensino de uma professora de inglês para surdos: a língua de sinais brasileira como mediadora do processo de ensino-aprendizagem. Revista Brasileira de Linguística Aplicada, 14(4). 